\title{
Henry Ford e a questão salarial
}

\section{Fábio San Martins}

Resumo: Henry Ford desenvolveu novas metodologias de produção que promoveram uma intensificação no regime de trabalho usual, demandando dos trabalhadores maior desgaste. A consolidação das novas metodologias fordistas de produção enfrentou resistência por parte dos trabalhadores. Henry Ford foi obrigado a enfrentar o problema dos salários e refletir sobre o seu papel na economia das empresas e no capitalismo em geral. Este artigo examina a ótica empresarial da questão salarial com base nas concepções de Henry Ford, e debate as suas ideias sobre os salários com as ideias dos estudiosos do "Five Dollar Day", a fim de realçar as contribuições desse autor.

Palavras-chave: Ford, força de trabalho, salário, racionalização da produção, intensidade do trabalho.

\section{Classificação JEL: J3; J5.}

Henry Ford and the Question Wage

\begin{abstract}
Henry Ford developed new methods of production that promoted an intensification in the usual working regime, demanding the increased wear workers. The consolidation of the new fordist production methodologies faced resistance from workers. Henry Ford was forced to face the problem of wages and reflect on their role in the economy of business and capitalism in general. This article examines the business perspective of the salary issue from Henry Ford's ideas. It discussed the Henry Ford's ideas on wages with the scholars of the "Five Dollar Day" to highlight the contributions of this author.
\end{abstract}

Key-words: Ford, workforce, wage, rationalization of production, work intensity.

JEL Classification: J3; J5.

1 Economista, Mestre em Economia, Doutorando pelo Programa de Pós-Graduação em Desenvolvimento Econômico (PPGDE/UFPR). E-mail: fluizmartins@gmail.com 


\section{Introdução}

As empresas procuram reorganizar o processo de trabalho, modificando os métodos de produção ou incorporando máquinas de alto desempenho, a fim de aumentar a escala de reprodução do seu capital. Graças à maior eficiência e intensidade do trabalho propiciada pela reorganização produtiva, a empresa pode gastar menos recursos produtivos para dado nível de produção, permitindo obter determinado montante de lucro com menor despesa de capital (presumindo constantes as demais circunstâncias).

Contudo, essa reorganização do processo de trabalho não é indiferente aos trabalhadores. As mudanças técnicas e de organização exigem deles menos interferência na concepção do plano de produção bem como uma mera adaptação à rotina e operação do processo de trabalho. Além disso, aquelas mudanças promovem uma intensificação do regime de trabalho acima do nível usual, demandando dos operários maior esforço e atenção. Desse modo, esses impactos imediatos da reorganização do trabalho e da produção sobre os trabalhadores tornam a questão salarial decisiva.

Henry Ford tornou-se célebre na história do capitalismo ao propor e desenvolver novas metodologias de produção e de trabalho. Entretanto, a consolidação dos novos métodos de produção nas suas fábricas de montagem de carros populares enfrentou, entre 1908 e 1914, séria resistência por parte dos trabalhadores, pois alteravam profundamente o modo como eles até então trabalhavam, tanto no sentido dos requerimentos de habilidades e conhecimentos necessários como na intensidade com que deviam empregar sua força de trabalho. Assim, Henry Ford não se ocupou apenas com a transformação das técnicas usuais de produção, sendo, também, obrigado a enfrentar os efeitos delas sobre os trabalhadores. A observação cuidadosa desses impactos levou Henry Ford a refletir, no âmbito de seu relato autobiográfico intitulado de My Life and Work de 1922, sobre o papel dos salários na economia das empresas.

O objetivo deste artigo é examinar o pensamento de Henry Ford apresentado na sua autobiografia acerca da questão salarial.

Este estudo está dividido em três seções (além desta introdução e a conclusão). Na primeira é discorrido o contexto do pensamento salarial de Henry Ford (1922). Esse dirigente industrial se ocupou do problema dos salários enquanto líder empresarial e suas ideias são gestadas com base nos ensinamentos das questões relativas à produção em série de modelos populares de carro que ocorreu em sua empresa de 1908 a 1914. A história do modelo T e as reformas de cargos e salários de 1913 e de 1914 são reconstituídas a fim de compor o contexto no qual as ideias de Henry Ford foram forjadas. Na segunda seção, estudam-se os principais traços das ideias e concepções de Henry Ford sobre os salários. Na terceira seção, são cotejadas as concepções de Henry Ford com as interpretações de alguns estudiosos como Gramsci (2001), Braverman (1998), 
Raff (1987) e outros sobre a controvertida reforma salarial "Five Dollar Day" (executada nas fábricas Ford no decorrer de 1914) no intuito de realçar as singularidades da visão fordiana.

\section{Mudanças técnicas e organizacionais na Ford e a reforma salarial de outubro de 1914}

As ideias de Henry Ford (1922) sobre os salários não formam uma teoria estruturada. Elas refletiam suas experiências no desenvolvimento da fabricação do célebre modelo T de automóvel. Por isso, é adequado, antes de estudar o pensamento fordiano acerca dos salários, descrever, ainda que sucintamente, um panorama da evolução do sistema de produção de automóveis na fábrica Ford desde sua fundação em 1903 até 1914 quando foi implementado o controvertido programa "Five Dollar Day". A maneira como Ford (1922) entendia a origem dos salários e suas múltiplas funções para a economia capitalista (tendo o setor automobilístico como unidade exemplar desse todo) amparava-se, como se verá, nas experiências com a produção em série do modelo T.

O período compreendido entre 1903 e 1914 pode ser dividido em duas fases. A primeira abrange os anos de 1903 a 1907, durante os quais a fábrica Ford empregava, ainda, o método de produção baseado na perícia de trabalhadores altamente qualificados; a segunda fase, situada entre os anos de 1908 e 1914, é o período em que ocorrerá o desenvolvimento da racionalização do trabalho e da mecanização do processo de trabalho com vistas à fabricação do modelo T (MEYER, 1981). A seguir, serão expostas as principais características de cada uma das fases com base nas informações reunidas pelos estudos de Meyer (1981) e Raff (1987), possivelmente duas das mais sistemáticas e profundas pesquisas sobre a gênese da produção em massa de automóveis nas fábricas Ford.

Na primeira fase da evolução da produção de carros pela Ford (1903-1907), a empresa aderia ao método tradicional que vigorava no incipiente ramo automobilístico americano. A Ford concentrava sua produção na montagem final de carros de luxo e encarregava a manufatura dos meios de produção às firmas externas, justamente pelo diminuto tamanho e volatilidade do mercado de veículos de luxo; a montadora poderia enfrentar significativos prejuízos se assumisse a produção dos próprios meios de produção diante de uma demanda relativamente acanhada e que oscilava sem tendência conforme os gostos e modismos dos consumidores de alta renda (MEYER, 1981). Para consecução desse processo de trabalho, a montadora encomendava peças e componentes junto a oficinas especializadas, cujos insumos não obedeciam a nenhuma especificação prévia, devendo, por isso, sofrer rigorosos ajustes dentro das fábricas Ford para serem posteriormente incorporados ao processo de montagem final de carros. Esses ajustes eram realizados por mecânicos competentes, dotados de grande capacidade técnica e conhecimento de seu ofício de natureza artesanal. 
Junto com a função de ajuste de peças e componentes encomendados às empresas externas, os mecânicos altamente qualificados também organizavam e tocavam o processo de montagem final dos carros. Esse processo de produção firmava-se, dessa maneira, nas habilidades especiais desses mecânicos e de seus ajudantes, que planejavam e concebiam o modo de operação do trabalho de montagem segundo seus conhecimentos e saberes acumulados no ofício. Desse modo, o processo de trabalho amparava-se na autonomia dos operários qualificados que fixavam o modo com que trabalhavam, de acordo com as leis do seu ofício sem interferência direta da empresa. A Ford limitava-se a estabelecer a extensão da jornada de trabalho e a quantidade média a ser produzida, segundo a procura volátil dos consumidores de alta renda (MEYER, 1981; RAFF, 1987).

Com efeito, a produção em larga escala de automóveis populares demandava a subordinação completa do processo de trabalho à lógica capitalista. A produção dificilmente atenderia aos requerimentos de eficiência exigidos pelo objetivo da lucratividade, enquanto o ritmo e velocidade do processo de trabalho continuassem dependendo das perícias do mecânico qualificado. A produção deveria ser reorganizada de modo que, para se atingir determinado volume médio de produção fossem exigidos relativamente menos recursos produtivos. Não bastava, para isso ocorrer, que a empresa se ocupasse apenas com a compra dos meios de produção e com a venda do produto final do processo de trabalho, enquanto a organização e desenvolvimento do processo produtivo fossem, ainda, regidos pelas habilidades e perícias dos trabalhadores mecânicos. Era indispensável que a Ford transformasse o processo de montagem de automóveis, de modo a ampliar a esfera de domínio da empresa sobre a concepção, o modo e velocidade de trabalhar e, assim, diminuir as influências diretas dos trabalhadores peritos sobre a dinâmica do processo produtivo. Para Meyer (1981) e Raff (1987), o controle do processo de trabalho pela Ford foi resultado da combinação do emprego dos métodos tayloristas de trabalho e da introdução do sistema de máquinas na produção.

O primeiro passo, nesse sentido, foi dado em 1906 com o processo parcial de manufatura das peças e componentes dentro do próprio estabelecimento da empresa. Com a produção interna desses insumos, foi possível estabelecer especificações rígidas sobre os modelos de peças e componentes, diminuindo a necessidade de ajustes posteriores. Tratou-se da primeira iniciativa da Ford de introduzir a lógica empresarial ao processo de trabalho e de reduzir o papel dos trabalhadores mecânicos qualificados em sua organização e execução (MEYER, 1981; RAFF, 1987).

É, entretanto, a partir do início da fabricação do modelo T, em 1908, que a batalha em torno do controle do processo de trabalho e sua submissão completa à lógica empresarial será vencida pela montadora Ford, culminando com a introdução, entre 1913 e 1914, da esteira rolante na linha de montagem dos carros. Cabe salientar a importância decisiva da produção em massa do modelo T no sucesso de libertar o processo de trabalho das antigas qualificações dos mecânicos e, consequentemente, subsumir a produção aos objetivos da própria Ford. 
A produção em larga escala de modelos em série de carros ensejou a busca de soluções de como organizar a produção de modo econômico e integrado. Parte dessas soluções incluiu o importante desenvolvimento da linha de montagem, método produtivo caracterizado por uma sucessão interligada de estações fixas de trabalho, de onde os trabalhadores transformavam, com a ajuda de equipamentos e outros materiais imediatamente à disposição, os produtos semielaborados das fases antecedentes. O desenvolvimento da linha de montagem estimulou acréscimo na intensidade do trabalho, posto que seu emprego depurava a jornada de trabalho de certas porosidades verificáveis, por exemplo, naqueles instantes em que o trabalhador realizava movimentos desnecessários à execução da tarefa e transitava improdutivamente de um local para outro do recinto laboral. A aplicação dos princípios tayloristas também fazia parte do rol das soluções da organização do trabalho; conforme a orientação de tais princípios, o processo produtivo passava por minuciosa avaliação e conhecimento, com base na qual engenheiros e administradores elaboravam o programa de execução das tarefas das distintas fases, cujo desenvolvimento deveria obedecer ao propósito de máxima eficiência dos movimentos corporais e do tempo. Com a adoção dos princípios tayloristas, as funções do trabalho tornaram-se mais simples e desqualificadas, porquanto o antigo saber dos mecânicos era apropriado pelos engenheiros e gerentes de produção e, mediante normas de execução, repassado de modo mais simples e elementar aos operários especialistas. Em cada etapa integrada da linha de montagem, os trabalhadores fixados em suas estações de trabalho executavam funções que se tornaram ainda mais simples e rotineiras graças à introdução de máquinas-ferramentas de última geração. Esses instrumentos de produção compunham-se de várias ferramentas, cujas operações transformavam o objeto do trabalho no produto planejado. A vantagem da máquina-ferramenta em relação à ferramenta manual consistia, primeiramente, no fato de que ela podia operar simultaneamente vários instrumentos, cujo ritmo de produção regulava-se por princípios mecânicos objetivamente definidos e livres, portanto, daquelas barreiras naturais representadas pelas mãos do trabalhador e pela força física com que o operário ditava as ações de suas ferramentas especializadas. E, depois, a ferramenta do mecânico manual lhe proporcionava considerável ingerência no processo de trabalho. A máquina-ferramenta retira das mãos desse mecânico perito a velha ferramenta especializada, inserindo-a num meio de trabalho mecanicamente regulado e, ao fazê-lo, limita as interferências dos trabalhadores no processo de trabalho a simples tarefas de monitoramento do movimento da máquina e de correção de eventuais erros, bem como as de suprimento de matérias-primas e de materiais auxiliares (para que o novo meio de trabalho pudesse operar e funcionar na plena eficiência).

De imediato, a diferença com o método tradicional de produção que vigorara até 1907 revelava-se, pelo fato de o antigo mecânico usar a totalidade de suas qualificações para estruturar e montar os veículos segundo um plano concebido por eles mesmos, com base nas experiências acumuladas com seu trabalho, cujas ferramentas e equipamentos puramente manuais requeriam treinamento e perícia especiais para serem manipulados adequadamente. Com o desenvolvimento do modelo $\mathrm{T}$ a partir de 
1908, os operários nada mais faziam, além de cumprirem as rotinas de trabalho fixadas pela gerência e supervisionarem a atividade automática das máquinas-ferramentas. Aquele antigo mecânico qualificado continuaria empregado na linha de montagem, porém em menor número e realizando funções tecnicamente mais simples, como consertos das avarias das máquinas-ferramentas e a inspeção do andamento da linha de montagem e da qualidade dos produtos semielaborados de cada etapa da produção, conjunto de ações que demandavam conhecimentos um pouco mais qualificados. De fato, com a nova metodologia de trabalho, as fases do processo de montagem tornaram-se plenamente integradas e inter-relacionadas. Cada etapa sucessiva dependia que os produtos semielaborados pela fase antecedente obedecessem às prescrições do programa de trabalho e ficassem prontos rigorosamente no tempo planejado. Com efeito, essa necessidade de organicidade da linha de montagem era assegurada por sua estrutura mecanizada, na qual a esteira rolante ocupava papel determinante. Por meio desse equipamento, eram transportados os produtos semielaborados de cada fase de montagem para às estações de trabalho particulares, proporcionando, com isso, maior grau de intensidade do fluxo de trabalho, além de praticamente eliminar os custos improdutivos de locomoção de operários e de materiais que tanto oneravam o processo produtivo no método antigo (MEYER, 1981; RAFF, 1987).

Em suma, a combinação entre o emprego dos princípios tayloristas e o uso de processos mecanizados (máquinas-ferramentas especializadas e linha de montagem unida à esteira rolante) aboliram, portanto, a primazia dos antigos mecânicos sobre o processo de trabalho. A produção é racionalizada, não porque aqueles que trabalhavam e produziam submetiam o trabalho à sua consciência e entendimento, mas porque estava organizada de maneira a produzir o máximo com o mínimo dispêndio de tempo e de recursos materiais conforme as determinações da gerência e do setor de planejamento da empresa ${ }^{2}$.

Esse conjunto de mudanças técnicas e organizacionais repercutiu, como era esperado, na quantidade de carros montados pela Ford que salta dos modestos 6.938 automóveis em 1908 para 248.307 veículos em 1914. O emprego de trabalhadores acompanhou o crescimento da produção partindo de 450 trabalhadores em 1908 para atingir um contingente de 12.880 em 1914 (Quadro 1, abaixo). Em 1914, o grupo ocupacional predominante era o de trabalhadores de pouca qualificação e de baixa experiência industrial, constituída, na sua maior parte, por imigrantes oriundos principalmente do sudeste europeu, uma região da Europa apoiada em atividades agropastoris de tipo tradicional ${ }^{3}$.

\footnotetext{
A propósito do conceito de racionalização, estudar BRAVERMAN (1998) e CORIAT(1989).

"This growth created a monumental labor problem a severe shortage of skilled mechanics who could machine and assemble parts for the popular Model T Ford. Consequently, the company hired large numbers of less-skilled and non-skilled American and immigrant workers. Prior to the rapid expansion in the workforce, Ford production workers were predominantly skilled American and German craftsmen. By 1914, three-quarters of the workforce was foreign-born and slightly more than half of the workforce came from southern and eastern Europe” (MEYER, 1981, p.10).
} 
Quadro 1: Produção e emprego nas fábricas Ford, entre 1908 e 1914

\begin{tabular}{|c|c|c|}
\hline Ano & Produção de veículos & Emprego \\
\hline 1908 & 6938 & 450 \\
\hline 1909 & 10607 & 1655 \\
\hline 1910 & 18664 & 2773 \\
\hline 1911 & 34528 & 3976 \\
\hline 1912 & 78440 & 6867 \\
\hline 1913 & 168220 & 14366 \\
\hline 1914 & 248307 & 12880 \\
\hline
\end{tabular}

Fonte: Extraído de Raff (1987, p.31 e p.136)

Nesse momento, cumpre destacar uma observação: o conjunto de mudanças técnicas e organizacionais, que especialmente a indústria automobilística sofreu no início do século XX nos EUA, não foi impulsionado em razão de uma suposta escassez da força de trabalho qualificada ${ }^{4}$, mas, ao contrário, porque tais habilidades e perícias representavam entrave à acumulação de capital das empresas $^{5}$. Era imprescindível submeter o trabalho ao controle capitalista para dotá-lo dos requerimentos necessários para se alcançar a finalidade da máxima eficiência e lucratividade. À medida que o modo de organização do trabalho passasse das mãos dos trabalhadores para as da administração e fossem introduzidos processos mecânicos à rotina de trabalho, seria possível produzir carros em série a baixo custo e a preços acessíveis à demanda de perfil mais popular e numerosa. Por outro lado, enquanto a Ford fosse a pioneira na adoção de métodos mais eficientes

4 Como assevera Meyer (1981, p. 10): "generally, American advances in industrial technology have been attributed to a shortage of skilled labor. Most certainly, such was the case for the Ford factory" e mais adiante confirma: "With advanced machine-tool technology, the division and subdivision of labor, and the novel techniques of line production and assembly, they relied on the traditional American solution to labor shortages" (Meyer, 1981, p.10).

5 Braverman (1998) sobre isso tece a seguinte reflexão: "In the mythology of capitalism, the Babbage principle is presented as an effort to 'preserve scarce skills' by putting qualified workers to tasks which 'only they can perform' and not wasting 'social resources'. It is presented as a response to 'shortages' of skilled workers or technically trained people, whose time is best used 'efficiently' for the advantage of 'society'. But however much this principle may manifest itself at times in the form of a response to the scarcity of skilled labor-for example, during wars or other periods of rapid expansion of production-this apology is on the whole false, The capitalist mode of production systematically destroys all-around skills where they exist, and brings into being skills and occupations that correspond to its needs, Technical capacities are henceforth distributed on a strict 'need to know' basis. The generalized distribution of knowledge of the productive process among all its participants becomes, from this point on, not merely 'unnecessary', but a positive barrier to the functioning of the capitalist mode of production” (Braverman, 1998, p.57). 
de produção, ela poderia usufruir de posição dominante no mercado e, com isso, apropriar os lucros extraordinários ${ }^{6}$.

Entretanto, as mudanças técnicas e organizacionais operadas a fim de viabilizar, entre os anos de 1908 e 1914, a produção do modelo T, ocorreram sem qualquer preocupação imediata da administração da Ford com a questão dos salários. Enquanto o processo de trabalho sofria alterações de fundo, sendo racionalizada e mecanizada conforme diretrizes emanadas da administração, os métodos de pagamento salarial continuavam rigorosamente os mesmos até 1912, com os supervisores de produção tendo a prerrogativa na definição da escala de salários e na gestão da mão-de-obra (sua contratação, demissão, seleção, alocação de funções). De fato, a incoerência entre o emprego de nova organização do trabalho de tipo racional e mecânico e uma estratégia de pagamento dos trabalhadores que seguia procedimento da época anterior às mudanças estruturais do processo de trabalho (que vinham se desenvolvendo desde 1908) representava o pano de fundo da chamada "crise de trabalho" de 1913 (MEYER, 1981; RAFF, 1987). Os desconfortantes indicadores de taxas de absenteísmo $(10 \%)$ e de rotatividade $(370 \%)$ davam testemunho da grave instabilidade do quadro empregatício das fábricas Ford durante a mencionada "crise de trabalho" de 1913 (RAFF; SUMMERS, 1986).

Com a finalidade de conter essa instabilidade no quadro de empregados, a direção da Ford realizou em sequência duas importantes reformas (MEYER, 1981; RAFF, 1987).

Em outubro de 1913, a Ford colocou em ação novas diretrizes para a gestão de pessoal e de pagamento salarial. Primeiramente, foram criadas faixas salariais por nível de desempenho e para cada uma dessas estabeleceu-se um reajuste de $15 \%$ em relação à média paga até aquele momento. O propósito era melhorar o padrão salarial médio, o qual sofrera uma marcante redução com o relaxamento das exigências de qualificação da força de trabalho pela linha de montagem mecânica e taylorista. Essa menor exigência de qualificação permitiu crescente emprego de mão-de-obra barata fartamente disponível no mercado de trabalho, em virtude do fluxo imigratório de grandes dimensões que se dirigia aos EUA no começo do século XX (MEYER, 1981; CORIAT, 1989). A direção da Ford previa que os salários médios mais elevados encorajariam vínculos de emprego de mais duradoura permanência, o que contribuiria para combater o absenteísmo e a alta rotatividade das ocupações na empresa. Combinado a isso, o aumento dos salários médios poderia, na avaliação da administração da Ford, facilitar a adaptação dos trabalhadores aos métodos novos de produção e de trabalho, pois lhes abriria a perspectiva

6 Raff; Summers (1986, p.9-10) estimam, por exemplo, que em 1913 a participação da Ford no mercado de carros populares nos EUA correspondia a $96 \%$ e a taxa de lucro sobre "ativos tangíveis" era de $118 \%$ : "It is indicative of the demand for Ford cars that the company was able to price in such a way that it earned profits equal to 31 percent of sales. The profitability reflected in part the popularity of Ford cars and in part the efficiency of Ford production techniques." (RAFF;SUMMERS, 1986, p.10) 
de saltar para faixas salariais mais altas conforme melhorassem o desempenho nas tarefas e funções (MEYER, 1981; RAFF, 1987). Outra medida importante da reforma de outubro de 1913 foi a criação de um departamento de emprego que se encarregaria de várias funções concernentes à gestão de pessoal, como registrar as informações referentes à movimentação de mão-de-obra, selecionar candidatos à vaga e estabelecer normas de demissão. Portanto, modificava-se a prática usual na montadora Ford de atribuir aos supervisores de produção o papel de selecionar, demitir e alocar mão-de-obra entre os setores da fábrica; essa função informal de gestor de pessoal exercido por tais supervisores frequentemente incitava queixas e insatisfações nos trabalhadores que interpretavam várias das medidas aplicadas como abusivas (demissão sem motivação) e injustas (salários diferentes para idêntico desempenho na tarefa) (MEYER, 1981).

A reforma de outubro de 1913 (também chamada Reforma Lee) foi um ensaio para um programa salarial mais estruturado e de maior gratificação: o "Five Dollar Day" (anunciado em janeiro de 1914). Essa reforma salarial estabelecia que o salário médio do trabalhador de menor qualificação subiria dos US\$2,50 correntes para US\$ 5 com jornada de trabalho reduzida de 9 para 8 horas diárias. Todavia, as condições de elegibilidade do programa eram bastante exigentes. Os homens muito jovens (abaixo dos 21 anos e que não eram arrimo de suas famílias) bem como as mulheres estavam excluídos do benefício. Já os potencialmente elegíveis (os homens acima de 21 anos) deveriam comprovar comportamento moral irretocável para assegurar o direito de receber o benefício e mantê-lo durante o período de vigência do "Five Dollar Day". As atitudes que pudessem implicar desconcentração no trabalho eram consideradas permissivas e moralmente condenáveis, sujeitando seus autores à punições, como suspensão temporária do benefício e, em casos de reincidência, sua revogação definitiva. A questão da austeridade moral dos beneficiários era considerada tão crucial no "Five Dollar Day" que a administração da Ford, durante o ano de 1914, criou um Departamento de Sociologia dedicado a pesquisar os hábitos de vida e de consumo dos beneficiários do programa, a fim de elaborar orientações de práticas austeras de moralidade pessoal e de formas corretas de efetuar os gastos salariais (MEYER, 1981; RAFF,1987).

\section{0 pensamento sobre os salários de Henry Ford em My Life and Work de 1922}

Qual era a posição de Henry Ford (1922) em relação às reformas salariais de 1913 e de 1914? Esse dirigente empresarial não desenvolveu uma "teoria” dos salários. Suas concepções acerca dos salários apoiavam-se na experiência como dirigente industrial, a qual lhe proporcionou um ponto de observação privilegiado das mutações técnicas e organizacionais de um dos ramos mais importantes da moderna economia dos EUA. Henry Ford (1922) não concebe o trabalhador como mero portador de fator de produção, pelo qual receberia um rendimento 
proporcional', e sim como possuidor de força de trabalho; essa simples circunstância leva o empresário a tirar conclusões acerca das funções dos salários, que demonstram uma compreensão acurada do mecanismo da produção capitalista, privilégio inegável de sua condição de líder industrial num momento crucial de mudanças técnicas e organizacionais de sua empresa.

Henry Ford (1922) principia seu pensamento dizendo que os salários nada mais são do que fração do próprio produto do trabalho diário dos trabalhadores:

I cannot see how under such conditions the men could possibly be paid more than ten or twenty cents a day-for of course it is not the employer who pays wages. He only handles the money. It is the product that pays the wages and it is the management that arranges the production so that the product may pay the wages. (FORD, 1922, p. 78).

Essa afirmação de Henry Ford (1922) evidencia que, para ele, os salários não representam propriamente um custo para os empresários, visto que os trabalhadores são pagos com uma parcela do próprio produto do trabalho. Esse pensamento fordiano serve ao propósito de também justificar o fundamento de sua visão de harmonia de interesses entre empresários e trabalhadores. Na medida em que os salários não representam custo propriamente dito, torna-se descabido os empresários buscarem rebaixá-los sem critério produtivo e tampouco sem sentido os trabalhadores reivindicarem um aumento salarial sem correspondência na produtividade:

\begin{abstract}
No man is independent as long as he has to depend on another man to help him. It is a reciprocal relation--the boss is the partner of his worker, the worker is partner of his boss. And such being the case, it is useless for one group or the other to assume that it is the one indispensable unit. Both are indispensable. The one can become unduly assertive only at the expense of the other--and eventually at its own expense as well. It is utterly foolish for Capital or for Labour to think of themselves as groups. They are partners. When they pull and haul against each other--they simply injure the organization in which they are partners and from which both draw support. (FORD, 1922, p. 117).
\end{abstract}

Por conseguinte, compete à administração da empresa organizar o mais eficientemente a produção e o trabalho, a fim de maximizar o produto, de modo que a cota dos trabalhadores na produção possa correspondentemente elevar-se: "and it is the management that arranges the production so that the product may pay the wages" (FORD, 1922, p. 78).

Ponto de vista diferente do de Taylor (outro expoente no desenvolvimento de novas metodologias de produção e de trabalho), que entendia os salários como rendimento de um ativo em mãos dos trabalhadores: “(...) and then keep na individual record of each man's work, and pay him just what he had earned” (TAYLOR, 1919, p. 77). 
A noção inicial fordiana de os salários serem pagos pela própria produção enseja estudo de outros aspectos desse rendimento. $\mathrm{O}$ trabalhador toda vez que trabalha põe em movimento sua força física e emocional, mas essa ação da qual consiste o trabalho não é simplesmente maquinal, mas, ao contrário, orientada por conhecimentos e saberes que lhe mostram como trabalhar e atingir adequadamente o objetivo proposto. Durante o processo de trabalho, o trabalhador mobiliza energias vitais de seu corpo e mente que demandam, para que essas sejam continuamente renovadas, o consumo de meios de subsistência passíveis de manter a pessoa no exercício da atividade, assim como sustentá-la antes e depois da conclusão de seu trabalho. Henry Ford (1922) evidencia, então, que a produção capitalista liga jornadas de trabalho sucessivas e, portanto, o trabalhador, para retornar cotidianamente à produção, precisa repor os gastos diários de sua força de trabalho. Nos trechos seguintes nota-se que Ford compreende que a cada jornada o trabalhador gasta energia (apesar das dificuldades com sua mensuração):

It costs just as much physical strength to turn out a day's work when wheat is $\$ 1$ a bushel, as when wheat is $\$ 2.50$ a bushel. Eggs may be 12 cents a dozen or 90 cents a dozen. What difference does it make in the units of energy a man uses in a productive day's work? (FORD, 1922, p. 122).

It is perhaps possible accurately to determine-albeit with considerable interference with the day's work itself —how much energy the day's work takes out of a man. But it is not at all possible accurately to determine how much it will require to put back that energy into him against the next day's demands. Nor is it possible to determine how much of that expended energy he will never be able to get back at all. (FORD, 1922, p. 124).

But pensions do not attend to the profit which each day's labour ought to yield in order to take care of all of life's overhead, of all physical losses, and of the inevitable deterioration of the manual worker. (FORD, 1922, p. 124).

Assim, o trabalhador, para produzir continuamente o produto global, requer que parcela equivalente desse último destine-se na forma de salário à recomposição dos gastos de força de trabalho consumidos durante a jornada. Os trabalhadores precisam, por isso, com seu salário, usufruir de um padrão de vida aceitável, caracterizado, segundo Ford (1922, p.116), não por uma situação de consumo abundante de bens de luxo e sim representado por um estilo de vida que possibilite aos operários restaurar a força de trabalho, de modo a possibilitar-lhes o seu retorno nas sucessivas jornadas. De fato, os salários devem recompensar o esforço dedicado à produção: 
The kind of workman who gives the business the best that is in him is the best kind of workman a business can have. And he cannot be expected to do this indefinitely without proper recognition of his contribution. The man who comes to the day's job feeling that no matter how much he may give, it will not yield him enough of a return to keep him beyond want, is not in shape to do his day's work. He is anxious and worried, and it all reacts to the detriment of his work. (FORD, 1922, p. 120).

Todavia, essa afirmação não equivale a um endosso de Ford (1922) ao entendimento dos salários como incentivo ao trabalho. O empresário, quando fala dos salários e produção, tinha em mente o processo de trabalho organizado segundo os princípios tayloristas e mecanizado pelo uso sistemático do maquinismo. A análise fordiana pressupunha o trabalhador destituído de qualquer possibilidade de fazer valer sua iniciativa e vontade no processo produtivo. Quando se refere ao salário como retribuição ao esforço dedicado, Henry Ford não está, com isso, afirmando que o salário deve ser de tal montante para extrair dos trabalhadores estímulo para o trabalho, posto que na linha de montagem o esforço já estava prescrito nas regras estabelecidas pela administração e pelo movimento mecânico da esteira rolante e das máquinas-ferramentas especializadas. Ao contrário, o salário deve compensar o esforço gasto pelo trabalhador para acompanhar, durante a jornada, o movimento mecânico, regular e intenso do processo de trabalho. Sem essa recompensa, o desempenho do processo de trabalho ficaria prejudicado em razão do caráter sincrônico e integrado da linha de montagem.

Por outro lado, o salário não cumpre apenas sustentar o trabalhador individualmente, mas também sua família:

But if a man feels that his day's work is not only supplying his basic need, but is also giving him a margin of comfort and enabling him to give his boys and girls their opportunity and his wife some pleasure in life, then his job looks good to him and he is free to give it of his best. (FORD, 1922, p.120).

Ford (1922), com essas palavras, demonstra entender que as empresas capitalistas têm o propósito de se manterem ativas por longos anos no mercado, exigindo que o contingente de trabalhadores fosse constantemente renovado e ampliado. Os salários satisfazem esse papel de provedor de mão-de-obra futura ao permitir que os trabalhadores formem famílias.

Amparado nas experiências de líder empresarial num período de importantes mutações técnicas e organizacionais de sua empresa, Ford (1922) revela uma compreensão aprofundada sobre os salários e de sua função no cotidiano das empresas. Segundo ele, para que a máxima eficiência da produção fosse plenamente satisfeita, as necessidades dos trabalhadores, por via de consequência, precisavam ser assistidas adequadamente pelos salários: “The wage carries all the worker's obligations outside the shop; it carries all that is necessary in the way of service and management inside the shop.” (FORD, 1922, p.120). Em outras palavras, a fim de que o 
produto global de dada jornada fosse atingido na plena eficiência, cumpria que aos trabalhadores fosse reservada uma fatia do que diariamente foi produzido na forma de salários, com a qual fosse possível consolidar um estilo de vida aceitável e do qual fosse permitido restaurar integralmente suas energias vitais gastas cotidianamente no trabalho (em consonância com as jornadas seguintes) e ainda sustentar sua família, de modo que uma nova geração de operários renovasse e ampliasse o atual contingente de mão-de-obra.

Esse pensamento de Ford (1922) oferece elementos para se compreender a finalidade das reformas salariais de outubro de 1913 (também chamada Reforma Lee) e de janeiro de 1914 ("Five Dollar Day"). O conjunto de mudanças técnicas e organizacionais do processo de trabalho empreendidas entre 1908 e 1913 nas fábricas Ford implicaram redução dos requerimentos de qualificação dos trabalhadores (FORD, 1922, p.87). Os salários imediatamente foram reduzidos, pois os antigos mecânicos qualificados foram desligados com o ingresso da maquinaria, enquanto outros foram substituídos por trabalhadores de origem imigrante com pouca qualificação e com salários mais baixos. Os poucos trabalhadores qualificados demandados pela nova organização realizavam funções mais simples do que as do tradicional mecânico, tais como efetuar reparos nas máquinas e monitorar a qualidade dos subprodutos de cada etapa do processo integrado de produção; seus salários foram também reduzidos a fim de alinhar-se às funções mais simplificadas que executavam. Entretanto, foi constatado, no período do desenvolvimento do modelo T, que a empresa tinha dificuldades de reter mão-de-obra, fato expresso nas persistentemente elevadas taxas de absenteísmo e rotatividade. Para Ford (1922), a empresa sofria de uma nova espécie de indisciplina operária ${ }^{8}$, diferente daquela tradicional tática de retardo e de restrição da produção tão habitual nas linhas de produção em que os métodos científicos e a mecanização ainda não estavam presentes?.

Ford (1922) considerava fundamental a obediência e disciplina dentro da fábrica: "We expect the men to do what they are told. The organization is so highly specialized and one part is so dependent upon another that we could not for a moment consider allowing men to have their own way. Without the most rigid discipline we would have the utmost confusion. I think it should not be otherwise in industry. The men are there to get the greatest possible amount of work done and to receive the highest possible pay. If each man were permitted to act in his own way, production would suffer and therefore pay would suffer" (FORD, 1922, p.111)

9 Ao comentar a deliberada tentativa dos operários de reduzir a intensidade de trabalho nos sistemas pre-taylorianos, Coriat (1989) interpreta que se tratava de uma maneira de os trabalhadores preservarem sua força de trabalho numa época histórica do desenvolvimento capitalista na qual ainda inexistiam sistemas estatais de seguridade social: "Recordemos que esta pretendida 'holganza sitemática' uncubre de hecho, durante el período examinzado, um modo de defensa desarollado por la clase obrera a la vez contra el ('prolongando' el trabajo se prolonga el tiempo de ocupación remunerada) y contra el desgaste demasiado precoz de su fuerza, en una época en la que no existián nuestras modernas 'prestaciones indirectas'; em esas condiciones, cualquier accidente o enfermedad acarreaba la expulsión pura y simples del proceso de producción y la perdida completa del salário" (CORIAT, 1989, p.24, nota 2). 
As taxas de absenteísmo, compreendidas por faltas ao trabalho sem anuência da direção, significavam, na visão fordiana dos salários, que os trabalhadores estavam lutando para preservar sua força de trabalho do uso intenso ocasionado pela nova organização racional da produção. Ora, a jornada de trabalho tornou-se mais intensa com os novos métodos produtivos e com a aplicação da maquinaria, em consequência dos quais se acentuou o desgaste da força de trabalho, ao passo que os salários não foram corrigidos imediatamente para compensar a maior intensidade do processo de produção. Por conseguinte, os trabalhadores abstinham-se de comparecer ao trabalho alguns dias do mês como forma de reduzir a pressão do novo sistema de produção sobre a sua força de trabalho.

Por seu turno, a alta rotatividade expressava igualmente tentativa de os trabalhadores preservarem sua força de trabalho do desgaste excessivo a que estavam sujeitos com a nova organização do trabalho na fábrica. Como a montadora Ford era naquele momento possivelmente a única empresa do setor automobilístico a adotar métodos organizacionais tayloristas conjuntamente com a mecanização do trabalho, os trabalhadores trocavam seus empregos naquela fábrica por ocupações em outras empresas do mesmo setor no intuito de ajustar seus recebimentos salariais ao desgaste efetivo de sua força de trabalho. $\mathrm{Na}$ ótica dos trabalhadores, o salário na fábrica Ford não compensava o desgaste infligido pela intensidade excessiva do uso da força de trabalho, sendo, por isso, aceitável buscar emprego em outra empresa mesmo recebendo eventualmente um salário mais baixo, mas que, em contrapartida, fosse ao menos suficiente para recompor o gasto efetivo de energia física e emocional consumido durante a jornada.

Como os trabalhadores, indaga Henry Ford, poderiam obedientemente atender aos requisitos esperados por suas funções rotineiras na nova organização do trabalho se o processo de trabalho lhes consumia em demasia a força de trabalho? As reformas salariais de 1913 e 1914, segundo Henry Ford, propunham ajustar os salários ao grau de desgaste e intensidade do uso da força de trabalho imposto pelo novo método de organização da linha de montagem. Assim, os salários altos constituíam um meio de obter disciplina dos trabalhadores. A empresa seria também favorecida com os salários altos, pois a indisciplina operária (revelada pelas altas taxas de absenteísmo e de rotatividade) impunha custos não desprezíveis, posto que a montadora se obrigava a manter um quadro de reserva de trabalhadores para substituir os ausentes no intuito de garantir que o processo de produção transcorresse suave e imperturbavelmente. A possível interrupção do processo de trabalho ou sua realização com descontinuidades aumentava os custos de manutenção dos maquinários além de causar um incremento indesejável nos estoques de materiais. Os salários altos promoviam restauração da força de trabalho, de acordo com o desgaste exigido pela nova organização do trabalho, permitindo, em consequência, vínculos empregatícios mais duradouros com a empresa. Com isso, diminuir-se-iam os riscos de quebra na continuidade do processo de trabalho, ao mesmo tempo seriam reduzidos os custos com seleção e treinamento de novos ingressantes. Final- 
mente, as despesas extraordinárias com a formação de um contingente de reserva de mão-de-obra para atender eventuais ausências e pedidos de desligamentos seriam praticamente extintas.

\section{A concepção de salário de Henry Ford em debate com as interpreta- ções das reformas salariais de 1913 e de 1914}

As reformas salariais de outubro de 1913 e de janeiro de 1914 suscitaram discussão sobre as suas causas e consequências. A exposição das ideias principais que orientaram essas interpretações e sua comparação com as de Ford (1922) permitirão realçar diversos aspectos singulares da visão fordiana dos salários.

Em seus "Cadernos dos Cárceres", Gramsci (2001) dedica uma reflexão sobre o "Americanismo e Fordismo" (datada de 1934). Na sua análise, os altos salários derivados, sobretudo, do programa "Five Dollar Day" estavam associados à intensidade acima da média que os métodos fordistas de trabalho impunham aos operários americanos. Com a racionalização do trabalho implantada nas fábricas da Ford, a jornada de trabalho tornou-se mais regular, motivando um maior desgaste da força de trabalho, o qual necessitava ser reposto com meios de vida e de consumo adicionais, a fim de garantir o retorno dos operários às jornadas subsequentes: "As iniciativas 'puritanas' têm apenas o objetivo de conservar, fora do trabalho, certo equilíbrio psicofísico, capaz de impedir o colapso fisiológico do trabalhador, coagido pelo novo método de produção" (GRAMSCI, 2001, p. 267).

As elevadas taxas de rotatividade e absenteísmo, que se verificaram no período anterior às reformas salariais fordistas de 1913 e 1914, são interpretadas por Gramsci (2001) como sintoma de que o sistema salarial vigente era incompatível com o novo grau de intensidade do uso da força de trabalho. Os salários altos, então, tomavam o duplo papel de, primeiramente, reintegrar a força de trabalho desgastada em excesso e, depois, de adaptá-la à nova organização racional do trabalho. Os salários, estando aquém do necessário para reintegrar a força de trabalho, impossibilitavam que os trabalhadores suportassem o ritmo do processo racional de trabalho, intensificado pelas normas da administração taylorista e pela velocidade dos processos mecânicos (esteira rolante e máquina-ferramenta). Os altos salários reporiam os gastos de força de trabalho empenhados durante o trabalho de grau de intensidade superior mediante o consumo adicional de meios de vida, com o que, adicionalmente, permitiria aos trabalhadores se adaptarem ao mecanismo racionalizado do processo de trabalho. Com efeito, os salários exerceriam um papel de "coação econômica" sobre os trabalhadores, no sentido de que a montadora Ford obteria a desejada obediência operária por meio de um sutil uso de "persuasão". De fato, os trabalhadores poderiam alternativamente adaptar-se à nova organização racional de trabalho pelo emprego aberto da violência, mas essa demandaria a consecução de um sistema dispendioso de monitoramento e de repressão e com resultados possivelmente duvidosos em matéria de adequação da força de trabalho ao sistema for- 
dista de produção. $\mathrm{Na}$ análise gramsciana, o dirigente industrial Henry Ford estava ciente da natureza especial da força de trabalho e concluíra que seria mais eficiente para o propósito da adaptação dos trabalhadores à produção racionalizada combater economicamente a indisciplina operária com a concessão de salários altos, dos quais se consolidaria acesso a melhores de condições de vida material ${ }^{10}$.

Gramsci (2001) sublinha que, ao lado do papel de instrumento de adaptação econômica dos trabalhadores, os salários altos também poderiam conter a evasão dos operários do sistema fordista de produção, circunstância de decisiva importância, posto que a nova organização do trabalho requeria um quadro estável de trabalhadores especialistas para assegurar a fluidez e harmonia do desenvolvimento de um processo de trabalho composto de fases integradas e sincrônicas ${ }^{11}$. Do mesmo modo, Gramsci (2001) interpreta criticamente a "moralidade" apregoada pelo programa "Five Dollar Day" como condição de acesso aos altos salários. A direção das fábricas Ford não estava interessada em restituir para os trabalhadores os significados e sentidos do processo de trabalho, tal como ocorria na figura do mecânico tradicional no início do desenvolvimento daquela empresa. A "moralidade" dos trabalhadores, para Gramsci (2001, p.267), estava sendo "esmagada" dentro da fábrica com os trabalhadores a executar maquinalmente ordens da gerência e a monitorar o movimento monótono das máquinas, tarefas que prescindiam dos atributos morais da imaginação e do pensamento próprios à natureza do trabalho em geral. Não era essa "moralidade" que importava ao "Five Dollar Day", mas a que concernia à necessidade de os trabalhadores desenvolverem hábitos de vida doméstica e de consumo concordantes com as novas rotinas do trabalho nas

10 "Mas por que essa instabilidade [absenteísmo e rotatividade]? Como é possível que um operário possa preferir um salário 'mais baixo’ àquele pago pela Ford? [...] a indústria Ford exige uma especialização, uma qualificação para seus operários que as outras indústrias ainda não exigem, ou seja, uma qualificação de novo tipo, uma forma de consumo da força de trabalho e uma quantidade de força consumida no mesmo tempo médio que são mais gravosas e extenuantes do que em outros locais, forma e quantidade que o salário não consegue compensar em todos os casos, não consegue reconstituir nas condições dadas pela sociedade tal como é [...] Parece ser possível responder que o método Ford é 'racional', isto é, deve se generalizar; mas, para isso, é necessário um longo processo, no qual ocorra uma mudança das condições sociais e dos costumes e hábitos individuais, o que não pode ocorrer apenas através da 'coerção', mas somente por meio de uma combinação entre coação (autodisciplina) e persuasão, sob a forma também de altos salários, isto é, da possibilidade de um melhor padrão de vida, ou talvez, mais exatamente, da possibilidade de realizar o padrão de vida adequado aos novos modos de produção e de trabalho, que exigem um particular dispêndio de energias musculares e nervosas.” (GRAMSCI, 2001, p.274-275).

11 "Constituir um quadro orgânico e bem articulado de operários fabris qualificados ou uma equipe de trabalho especializada jamais foi tarefa simples: ora, uma vez constituídos esse quadro e essa equipe, seus componentes, ou parte deles, acabam por vezes não só se beneficiando com um salário de monopólio, mas também não são demitidos no caso de uma redução temporária de produção; seria antieconômica dispersar os elementos de um todo orgânico constituído com esforço, já que seria quase impossível voltar a agrupá-lo, na medida em que a reconstrução deste todo com elementos novos, aleatórios, custaria tentativas e gastos não indiferentes.” (GRAMSCI, 2001: 275) 
fábricas Ford. Os trabalhadores deveriam usar o acréscimo salarial para comprar apenas aqueles bens cujo consumo e uso pudesse reintegrar a força de trabalho e dotá-la de maior eficiência no processo produtivo racionalizado. Daí, segundo Gramsci (2001), o sentido da prédica fordiana contra o consumo de bebidas alcoólicas e de outros hábitos de mesmo gênero:

\begin{abstract}
Mas o alto salário é uma arma de dois gumes: é preciso que o trabalhador gaste "racionalmente" o máximo de dinheiro para conservar, renovar e, se possível, aumentar sua eficiência muscular-nervosa, e não para destruí-la ou danificá-la. E é por isso que a luta contra o álcool, o mais perigoso agente de destruição das forças de trabalho, torna-se função do Estado. (GRAMSCI, 2001, p. 267).
\end{abstract}

Notam-se as afinidades, em grandes linhas, do pensamento de Gramsci (2001) com as ideias sobre a natureza e papel dos salários de Henry Ford expostas em $M y$ Life and Work (1922). Essa constatação realça uma vez mais a clareza com que Henry Ford observava suas experiências como líder industrial, as quais lhe permitiram compor uma visão do salário com notável profundidade e realismo.

Gramsci (2001), todavia, introduz elementos novos que estão ausentes em Ford (1922). Gramsci, como Henry Ford, entendia que os altos salários seriam pagos com parcela dos lucros de "monopólio" advindos do domínio temporário ${ }^{12}$ de uma tecnologia de produção mais eficiente do que a usualmente adotada pelo conjunto dos demais competidores ${ }^{13}$. Entretanto, a difusão pela concorrência do método mais eficiente de produção faria desaparecer os lucros de monopólio que alimentavam os altos salários. Nesse estágio mais avançado, a adaptação dos trabalhadores ao processo de trabalho fordista se daria pelo apelo ao excedente de mão-de-obra de reserva justamente formado com a aplicação generalizada de maquinaria e dos métodos racionais de trabalho. A rotatividade, desse modo, seria contida pelo desemprego que, enfim, substituiria "coação econômica" dos salários ${ }^{14}$.

Essa exposição de Gramsci (2001), embora coerente com o marco teórico marxista, não concorda com as ideias de Ford (1922). O desemprego para Ford (1922, p. 153-154) era temporário e fruto de um período de transição durante o qual

12 A esse propósito, vale sublinhar que o programa "Five Dollar Day" tinha um caráter temporário, de maneira que a bonificação era destacada do salário básico no contracheque do empregado e discriminada como gratificação mensal paga como uma proporção dos lucros estimados (MEYER, 1981). Ralf; Summers (1986, p.15-16) calcularam que o custo previsto do programa foi da ordem de $50 \%$ dos lucros esperados para 1914

13 "Na realidade, a indústria americana que paga altos salários desfruta ainda de um monopólio que resulta do fato de ter a iniciativa dos novos métodos; aos lucros de monopólio correspondem salários de monopólio" (GRAMSCI, 2001, p. 273).

14 "Mas tão logo os novos métodos de trabalho e de produção se generalizem e difundirem, tão logo o novo tipo de operário for criado universalmente e o aparelho de produção material se aperfeiçoar ainda mais, o turnover excessivo será automaticamente limitado pelo desemprego em larga escala e os altos salários desaparecerão.” (GRAMSCI, 2001, p. 273). 
mudanças organizacionais e técnicas num determinado setor da economia expelem o excesso de trabalhadores e de capital, que, todavia, encontrarão, cedo ou tarde, emprego produtivo em outros ramos da atividade econômica. Para Henry Ford, os salários altos continuariam a exercer permanentemente papel na adaptação dos trabalhadores às contínuas mudanças técnicas e organizacionais. $\mathrm{O}$ desaparecimento dos lucros extras (que serve de fonte para os salários altos) pela difusão das melhores técnicas produtivas induz a adoção de outras ainda mais eficientes que, depois, proporcionarão provisoriamente lucros acima do médio. Dado que desemprego é passageiro e, por isso, não tem qualquer papel econômico, os salários relativamente altos devem, segundo Henry Ford, ser mantidos persistentemente para promover a adaptação dos trabalhadores às mudanças de produção que alteram sistematicamente a intensidade da força de trabalho em relação à intensidade usual.

Braverman (1998) defende a visão de que as mudanças técnicas e organizacionais que a montadora Ford empreendeu entre os anos de 1908 e 1914 tinham o intuito de estabelecer o controle empresarial sobre o processo de trabalho firmado até aquele período nos saberes e práticas dos mecânicos profissionais. Sustenta que, sobretudo, o programa "Five Dollar Day" teve a intenção de promover a adaptação dos trabalhadores à nova organização técnica e racional de trabalho.

Braverman (1998) interpreta "Five Dollar Day" como uma reação da fábrica Ford ao ascendente movimento sindical em Detroit durante a década de 1910'. De fato, com o incremento salarial levado a cabo pelo "Five Dollar Day", os trabalhadores ficariam protegidos de eventos imprevistos, como acidentes e doenças, além de permitir-lhes vislumbrar algum amparo na velhice na ausência de seguros públicos. E era justamente esse papel previdenciário dos salários uma das principais bandeiras de mobilização sindical nos anos 1910, de modo que sua inclusão nos ganhos salariais pelos trabalhadores da montadora Ford esvaziaria boa parte das demandas sindicais, logrando, em consequência, conquistar o apoio operário às diretrizes da empresa ${ }^{16}$.

Vale advertir que, na visão de Ford (1922), os salários deveriam manter a força de trabalho incluindo as necessidades de proteção à saúde, velhice e contra riscos acidentários: "And certainly it [salários] ought to be made to take care of the worker's sunset days when labour is no longer possible to him-and should be no longer necessary" (FORD, 1922, p.122). Dessa maneira, essa compreensão de Henry Ford não se originava, ao contrário do que pensa Braverman (1998), de sua luta contra a influência sindical, mas do seu entendimento do papel dos salários na reposição do desgaste da força de trabalho para o funcionamento normal dos empreendimentos industriais. Razão pela qual Henry Ford considerava os sindicatos

15 "The crisis Ford faced was intensified by the unionization drive begun by the Industrial Workers of the World among Ford workers in the summer of 1913.” (BRAVERMAN, 1998, p. 103)

16 "Although this dramatic increase in wages was not so strictly adhered to as Ford would have had the public believe when he launched it, it did raise pay at the Ford plant so much above the prevailing rate in the area that it solved both threats for the moment." (BRAVERMAN, 1998, p. 103). 
como desnecessários, porquanto acreditava que eles deixariam de existir à medida que as empresas racionalmente administradas passassem a apurar máxima produção, com o que seria permitido pagar salários condizentes com sua função econômica. Ford, assim, no seu esquema analítico não vincula diretamente os salários altos a um propósito de conter movimentos sindicais como interpreta Braverman (1998).

Braverman (1998) também concebe a alta dos salários como uma iniciativa de conter as elevadas taxas de rotatividade e de absenteísmo, as quais, segundo ele, se originavam da "impopularidade" dos empregos na montadora Ford" ${ }^{17}$ Todavia, recorde-se que Ford (1922) acreditava que realmente a majoração dos salários poderia refrear a instabilidade dos vínculos empregatícios, fato marcante no período (1908-1914) de emergência dos novos métodos de produção e de trabalho. Entretanto, para Henry Ford, as elevadas taxas de absenteísmo e de rotatividade nasciam de uma incompatibilidade entre os sistemas de salário vigente na empresa e o novo grau de intensidade da força de trabalho. Henry Ford pensava que a instabilidade de indicadores de vínculo de emprego refletia, na verdade, inadaptabilidade dos trabalhadores ao novo regime de trabalho e uma forma de desobediência tácita por meio da qual os operários adotavam a via do descanso informal e da troca de emprego como medida de alinhamento dos salários recebidos ao gasto efetivo de força de trabalho na produção. Braverman (1998), desse modo, ignora completamente a relação estabelecida por Henry Ford entre salário e reposição da força de trabalho gasta na produção.

Para Braverman (1998), o regime de trabalho taylorizado e mecanizado tornou-se tão monótono e rotineiro que a escalada do absenteísmo e da rotatividade expressava a "impopularidade" das tarefas dentro da fábrica Ford. Os salários altos serviriam ao propósito de compensar o caráter tedioso e "degradado" do trabalho. Essa interpretação de Braverman é contestada por Ford (1922). Na visão fordiana é equivocado reputar os empregos e funções no novo sistema de trabalho e de produção como desprovidos de inteligência, como se isso fosse um aspecto do trabalho ressentido pela maioria dos trabalhadores (FORD, 1922, p. 105-106). Os trabalhadores em geral não se inclinavam a assumir responsabilidades e se sentiam satisfeitos em serem dirigidos pela alta administração. Ford (1922) interpretava que a "insatisfação" dos trabalhadores (que não é organizada e consciente, mas assume formas de indisciplina e desobediência tácitas como "fuga ao trabalho") não era orientada para o trabalho em si, mas ao fruto dele, os salários. Henry Ford compreendia profundamente o sistema empresarial e sabia que ele não estava voltado para oferecer empregos nos quais os trabalhadores sejam recompensados intelectual e emocionalmente e sim para produzir mercadorias do modo mais eficiente possível, para assegurar conjuntamente altos lucros e salários. Ademais, Henry Ford sabia também que os trabalhadores teriam pouca chance de encontrar empregos em que

17 "In this move can be seen a second element in the adjustment of workers to increasingly unpopular jobs.” (BRAVERMAN, 1998, p.103) 
pudessem ter iniciativa e pensamento, à medida que a concorrência difundisse os novos métodos de trabalho. Assim, para Ford os trabalhadores resistiam não à "impopularidade" do regime de trabalho e sim à destruição acelerada de sua força de trabalho ocasionada por um inadequado sistema de salários.

Por último, Braverman (1998) considera que os salários relativamente altos atrairiam novos trabalhadores ao mercado de trabalho e esse excedente de mão-de-obra exerceria uma pressão sobre os atuais empregados na fábrica Ford para se adaptarem ao novo regime de produção, sob o risco de serem substituídos por outros mais conformados à disciplina do trabalho racionalizado ${ }^{18}$. Entretanto, Ford (1922), como dito anteriormente, não reconhece no excedente de mão-de-obra no mercado qualquer papel na regulação da intensidade da força de trabalho. Para ele, esse contingente de trabalhadores desempregados é temporariamente formado, de sorte que não é factível empregá-lo como mecanismo de adaptação dos trabalhadores ao novo sistema de organização do trabalho e de produção. Para Ford, os salários foram elevados sem qualquer relação com o objetivo de atrair novos trabalhadores ao mercado de trabalho e sim com a preocupação central com a restauração da força de trabalho excessivamente desgastada por processos de trabalho mais intensos como fator decisivo para consolidar a necessária fluidez e suavidade do novo processo produtivo.

A análise de Coriat (1989) atribui grande importância ao "consumo produtivo da força de trabalho". Assim, o programa "Five Dollar Day" restabeleceria a força de trabalho desgastada pelo seu intenso consumo produtivo ocasionado pelos novos métodos, além de permitir ao trabalhador resguardar as condições de sua vida doméstica (CORIAT, 1989, p.60). Portanto, Coriat (1989) alinha-se com as ideias de Ford (1922) para quem os salários devem cobrir as necessidades do trabalhador e da sua família e que tais necessidades uma vez atendidas revertem a favor da própria produção que terá de volta o operário completamente disponível para seguir a disciplina exigida pelo regime fordista de produção. A tentativa de controle dos gastos dos trabalhadores por meio das regras de acesso ao benefício do "Five Dollar Day" e do monitoramento pela equipe de investigadores do Departamento de Sociologia da Ford se justificava, segundo Coriat, pelo objetivo de incentivar a restauração da força de trabalho e de colocá-la em condições de consumo produtivo em cada jornada. Contudo, Coriat (1989, p. 55), entende, como Braverman (1998), que os salários altos tinham o propósito de atrair novos ingressantes ao mercado de trabalho e estimular adequação dos trabalhadores ao novo regime de produção pela ameaça de substituição. Em oposição, Ford (1922) não cogitou essa hipótese, de modo que os salários altos consistiam no único meio de adaptação econômica dos trabalhadores, intencionado pela reforma salarial fordista de 1914.

18 "It gave the company a large pool of labor from which to choose and at the same time opened up new possibilities for the intensification of labor within the plants, where workers were now anxious to keep their jobs.” (BRAVERMAN, 1998, p.103) 
Raff; Summers (1986) e Raff (1987) pretendem verificar a plausibilidade da hipótese do salário eficiência como fundamento explicativo para o programa "Five Dollar Day”. Segundo essa hipótese ${ }^{19}$, os empresários em virtude do conhecimento limitado sobre o real potencial de trabalho dos seus empregados relutam em reduzir os salários perante uma alta oferta de trabalhadores no mercado, justamente porque essa baixa salarial poderia afetar o comprometimento, a lealdade e o esforço. Assim, os salários mais altos do que o nível que equilibra o mercado de trabalho permitiria reduzir os custos de "turnover" e de absenteísmo bem como limitaria a influência dos sindicatos.

A conclusão dos estudos de Raff; Summers (1986) e Raff (1987) é a de que vários aspectos da hipótese do salário eficiência foram confirmados no episódio do "Five Dollar Day". Os salários altos foram estabelecidos para influir na postura dos trabalhadores de diversas maneiras. Os métodos de trabalho e de produção exigiram consideráveis investimentos em ativos fixos, e a linha de montagem, para funcionar adequadamente, demandava integração e sincronia entre as diversas fases do processo produtivo. Qualquer perturbação acarretava custos inesperados com manutenção de maquinário e de treinamento de pessoal para substituir os ausentes. Os salários altos em relação à mera produtividade marginal do trabalho foram, assim, fixados para conquistar o consentimento dos trabalhadores ao emprego da nova organização do trabalho e da produção, consentimento esse reputado estratégico para sua viabilidade econômica ${ }^{20}$. Por outro lado, os salários foram estabelecidos em níveis elevados com o intuito de obter a lealdade dos trabalhadores e retirá-los da esfera de influência dos sindicatos ${ }^{21}$. A "paz industrial", assim "comprada", contribuiria para manter a fluidez do processo integrado e sincrônico de trabalho, posto que uma das fontes de perturbação (o ativismo sindical) seria contida. Ademais, na perspectiva dos trabalhadores, os altos salários infligiriam um custo de oportunidade caso o operário fosse demitido, motivando-o a empenhar maior esforço e zelo na sua atual função' ${ }^{22}$. Do mesmo modo, esse esforço seria também obtido com a instituição de regras claras de demissão do

19 A propósito da teoria do salário eficiência e de suas diversas vertentes interpretativas consultar Katz (1986) e AMADEO; ESTEVÃO (1994).

20 "My hipothesis is that Ford was trying to buy an amicable acquiescence to the changes it was effecting (change whith employees would know it effecting) in work content (effort demands) and in work experience. Both the latter changes were clearly of some importance to works." (RAFF, 1987, p. 140).

21 "And the changing technology increased the importance to Ford of 'buying the peace' and avoiding systematic soldiering and output restriction or other collective action by his workforce" (RAFF; SUMMERS, 1986, p.32)

22 "A third alternative explanation for how a wage increase might raise productivity is that higher wages might elicit increased effort. Suppose effort is verifiable only at some cost. If wages are set at a level at which there is a utility cost to losing a job, workers will autonomously choose to work harder: high wages will substitute for monitoring and control.” (RAFF; SUMMERS, 1986, p.32). 
quadro de funcionários da montadora Ford, que foi uma das medidas mais importantes colocadas em prática pela reforma de outubro de 1913. Os trabalhadores teriam clareza de que os salários acompanhariam esforço empenhado e de que seu desligamento seria justificado pelo descumprimento das metas estabelecidas e anunciadas para a função. Assim, a substituição das medidas arbitrárias de reajuste salarial e de demissão vigentes até outubro de 1913 por normas claras de ascensão salarial e de demissão em caso de insucesso constituiu, para a hipótese de salário eficiência, uma tentativa de extrair dos trabalhadores tudo o que poderiam dar em fluxo de trabalho (RAFF; SUMMERS, 1986, p. 19-20).

A análise de Raff; Summers (1986) e Raff (1987), a despeito de chamar a atenção para vários aspectos importantes da problemática salarial do episódio do "Five Dollar Day", deixa de lado o que para Ford (1922) era central: os salários deveriam ser realinhados para restaurar a força de trabalho. O referencial teórico no qual está assentada a hipótese do salário eficiência não vincula o salário à reposição do desgaste da força de trabalho; assume, ao contrário, que o salário real competitivo representa a parcela da contribuição do trabalhador na produção. $\mathrm{O}$ salário real deve ser fixado acima desse nível competitivo sob a justificativa de assim obter o desejado esforço dos trabalhadores, vistos os empresários desconhecerem a real operosidade deles. Para Ford (1922), não se tratava de incentivar os trabalhadores a se esforçarem, porque o ritmo de produção estava sob o comando da administração por meio da fixação de regras taylorizadas para o exercício das funções e pelo emprego do maquinismo (esteira rolante e máquinas-ferramentas especializadas), cujas operações eram apenas supervisionadas pelos operários. Com a nova organização do trabalho, os trabalhadores não dispunham de meios para regular conforme sua vontade o ritmo de produção. Por outro lado, essa sujeição dos trabalhadores ao ritmo mais intenso dos novos métodos de trabalho e de produção causava um desgaste gravoso de sua força de trabalho não compensado pelo sistema salarial em vigor. Daí Henry Ford, como dirigente industrial, reconhecer nas surpreendentes taxas de absenteísmo e de rotatividade indisciplina operária prejudicial ao próprio curso normal da linha de montagem. Raff; Summers (1986) e Raff (1987) supõem, na sua análise, um estágio de processo de trabalho pré-fordista no qual o trabalhador ainda exercia sua atividade segundo um ofício, valendo-se dos seus saberes para guiar a atividade. Nessas circunstâncias, os salários poderiam, de fato, funcionar como estímulo para induzir mais intensidade e esforço dos trabalhadores, tendo em vista que o ritmo de trabalho era regulado por suas habilidades, mas não era o caso de um processo de trabalho já completamente racionalizado pelo taylorismo e pelo maquinismo como o da montadora Ford.

$\mathrm{Na}$ ótica de Henry Ford, de igual modo, não é possível concordar que os salários foram elevados para obter o "consentimento" dos trabalhadores ao novo regime de trabalho racionalizado. Novamente, fica patente que Raff; Summers (1986) e Raff (1987) ignoram que a estrutura de produção da montadora Ford mediante uso sistemático de maquinaria e dos princípios tayloristas retirou com- 
pletamente dos trabalhadores qualquer poder de regulação do ritmo de trabalho. Os autores estão corretos, segundo Ford (1922), quando chamam a atenção que o excessivo absenteísmo e rotatividade prejudicavam o andamento suave e normal do processo de trabalho e que isso onerava a empresa. Equivocam-se, contudo, ao afirmar que a consolidação de tal harmonia na produção e no trabalho obrigasse a empresa ceder um aumento de salário aos trabalhadores, a fim de conquistar-lhes o consentimento ao novo regime de trabalho. A adaptação à nova organização não comprovaria a anuência e satisfação dos trabalhadores em relação à rotina do trabalho taylorizado e mecanizado; revelaria, para Henry Ford, que o novo grau de intensidade do uso da força de trabalho exigido pelo método de trabalho estava sendo compensado pelos salários. Ford, como realçou também Gramsci (2001), estava preocupado em constituir um quadro estável de trabalhadores, perfeitamente adaptado à nova organização de trabalho, a fim de sustentar as propriedades ótimas de regularidade e intensidade da linha de montagem. Os salários jogariam papel decisivo nessa estabilidade, porque permitiriam restaurar a força de trabalho e adaptá-la ao novo regime de produção.

\section{Conclusão}

A questão salarial jogou papel-chave nas pioneiras mudanças técnicas e organizacionais de trabalho durante a implementação, entre os anos de 1908 e 1914, da fabricação de carros populares em série nas fábricas Ford. A instabilidade do quadro ocupacional (medida pela forte ascensão das taxas de absenteísmo e de rotatividade que acompanhou o desenvolvimento da produção em massa de automóveis) levou a direção da Ford entre outubro de 1913 e de janeiro de 1914 (respectivamente, Reforma Lee e programa "Five Dollar Day") a consecução de reformas no plano de cargos e salários, a fim de ajustar os rendimentos salariais ao novo maior grau de intensidade do trabalho.

Henry Ford, na condição de dirigente industrial, relatou, na sua conhecida autobiografia My Life and Work de 1922, a experiência do período de gestação e consolidação do modelo de produção em massa de carros nas suas fábricas entre 1908 e 1914. Nesses relatos, o célebre empresário dedicou especial atenção ao contexto de instauração do controvertido programa "Five Dollar Day" com o que foi permitido, neste artigo, compreender sua visão sobre a natureza e papel dos salários na economia.

Henry Ford no seu relato autobiográfico deixou patente que não concebia o salário como uma quantia que expressaria, em determinada situação de mercado, a remuneração que o trabalhador teria direto pela posse de ativo específico representado pelo seu trabalho. Ao contrário, entendia claramente o trabalhador como possuidor de força de trabalho, cujo pagamento salarial deve assegurar reprodução da vida material do operário e de sua família, bem como garantir reposição das energias vitais consumidas durante o empenho da jornada. É uma concepção que supõe uma 
compreensão mais aprofundada do mecanismo da produção industrial em moldes empresariais. Para Henry Ford, em razão da pressão concorrencial, as empresas são impelidas a produzir com máxima eficiência, para o que modificam insistentemente os métodos de trabalho. Acontece que tais métodos alteram o grau de intensidade do trabalho repercutindo sobre o desgaste do trabalhador, cuja reposição demandava consumo suplementar de artigos de subsistência para proporcionar permanente retorno dos trabalhadores às jornadas subsequentes. Razão pela qual, os salários altos, então, assumiam a dupla função de, primeiramente, recuperar o desgaste da força de trabalho infligido pelos novos métodos de produção e, depois, de adaptar os trabalhadores à nova organização racional do trabalho, caracterizada pelas rígidas normas da administração taylorista e pela velocidade mais acentuada dos processos mecânicos (esteira rolante e máquina-ferramenta). A última função dos salários mais altos era de especial relevância, posto que, ao conter o absenteísmo e a rotatividade do quadro ocupacional, possibilitaria a constituição de um quadro estável de trabalhadores, fato de fundamental importância para assegurar a fluidez e harmonia do desenvolvimento de um processo produtivo caracterizado por fases integradas e sincrônicas. Nesse sentido, o desemprego, para Henry Ford, não tinha qualquer significação econômica, posto que fosse de caráter passageiro e resultado de um período em que mudanças organizacionais e técnicas são consolidadas, mera transição ao final da qual o excesso de trabalhadores e de capital serão inteiramente absorvidos em outros ramos da atividade econômica. Logo, os salários relativamente altos deveriam ser duradouramente empregados para promover a adaptação dos trabalhadores às mudanças de método produtivo e na organização do trabalho, em virtude das suas repercussões sobre o desgaste da força de trabalho.

\section{Referências}

AMADEO, Edward J.; ESTEVÃO, Marcello. A teoria econômica do desemprego. Hucitec, 1994.

BRAVERMAN, Harry. Labor and monopoly capital: the degradation of work in the twentieth century. New York: Monthly Review Press, 1998.

CORIAT, B. El taller y el cronometro: ensayo sobre el taylorismo, el fordismo y la produccion en masa. 4.ed., Madrid: Siglo XXI, 1989.

FORD, H. (with the assistance of S. Crowther), My Life and Work. New York: Doubleday, Page \& Company, 1922

GRAMSCI, Antonio. Americanismo e Fordismo. In: Cadernos do cárcere, Rio de Janeiro: Civilização Brasileira, 2001, Vol.4. 
KATZ, L.F., Efficiency Wage Theories: A Partial Evaluation. In FISCHER, Stanley (org.), NBER Macroeconomics Annual,1986, volume 1. crossref https://doi.org/ $10.1086 / 654025$

MEYER, Stephen. The Five Dollar Day: Labor Management and Social control in the Ford motor Company 1908-1921. Albany: State University of New York Press, 1981

RAFF, D. M. C., Wage Determination Theory and the Five Dollar Day at Ford: A Detailed Examination Massachusetts: Department of Economic (MIT), 1987 (Tese, Doutorado)

RAFF, D. M. C; SUMMERS, Lawrence H. Did Henry Ford pay efficiency Wages? NBER Working Paper, Discussion Paper; no. 2101, Cambridge, MA: NBER, 1986

TAYLOR, F. W. The Principles of Scientific Management. New York and London: Harper \& Brothers Publishers, 1919

Recebido em 27.04.16

Aprovado em 14.12.16 
